\title{
HUBUNGAN STRATEGI GURU TERHADAP KEMAMPUAN BACA AL- QUR'AN DI SMA DWIWARNA BOARDING SCHOOL PARUNG BOGOR
}

\author{
Khairunnisa Mahfuzd $^{1}$, Gunawan Ikhtiono ${ }^{2}$, Kholil Nawawi ${ }^{3}$ \\ Universitas Ibn Khaldun Bogor
}

\begin{abstract}
The relation between teacher strategies and the ability to read the qur'an in High School of Dwiwarna Boarding School of Parung Bogor.. Skripsi. Major of Islamic Religious Education. Islamic Religious Faculty of Ibn Khaldun University. The Mentors : Gunawan Ikhtiono, Kholil Nawawi.

The teacher strategy is a learning activity that must be used by teachers and students so that learning objectives can be achieved effectively and efficiently. The learning strategy is an action plan (a series of activities) including the use of methods and the use of various resources or strengths in learning. Therefore, it is reason for PAI teachers to be able to facilitate their students by teaching the alqur'an in accordance with the teaching strategy. Because the information will be well received by students and learning can achieve optimal results. Therefore, this study aims to determine how the relationship between teacher strategies and the ability to read the qur'an at SMA Dwiwarna Boarding School Parung Bogor. This study uses a quantitative approach. Technique school Parung Bogor, amounting to 95 students. The data analysis technique in this research is SPSS 23.0 for windows.
\end{abstract}

Based on the result of above analysis can be summarized that variable correlation value $X$ and $Y$ are 0,90, if observed from interpretation table the value that is gotten is 0,90 which is located between 0,70-0,90. Viewed from data interpretation it is included to strong correlation. Then by viewing table value on " $r$ " with its significant value obtained " $r$ " table is 0,2272. Therefore, on significant degree 5\% " $r$ " counting $+0,90>$ from " $r$ " table $=0,2272$, it means alternate hypotheses $(\mathrm{Ha})$ is received and $(\mathrm{Ho})$ is rejected. So, there is significant relation between teacher strategies and the ability to read the qur'an in High School of Dwiwarna Boarding School of Parung Bogor.

Keywords: teacher strategies, read the qur'an, the ability to read the qur'an.

\section{PENDAHULUAN}

Dalam proses pendidikan formal, kegiatan belajar mengajar merupakan kegiatan pokok yang sangat penting dalam mencapai tujuan pendidikan. Proses belajar mengajar selalu terjadi dalam kehidupan kita setiap saat, dengan disengaja ataupun tidak disengaja, disadari atau tidak disadari. Dari proses belajar mengajar ini akan memperoleh suatu hasil, yang mana hasil tersebut pada umumnya disebut hasil pembelajaran. Untuk memperoleh hasil yang memuaskan, proses belajar mengajar harus dilakukan dengan usaha sadar dan sengaja serta terorganisasi secara baik. ${ }^{1}$

\footnotetext{
${ }^{1}$ Rumpakawati W, (2015), Pembelajaran Kooperatif dengan Metode Numbered Heads Togther
} 
Belajar adalah kunci yang sangat penting bagi kehidupan terutama dalam setiap usaha pendidikan, sehingga tanpa belajar sesungguhnya tidak pernah ada pendidikan. Adapun definisi lain dari belajar adalah suatu kegiatan yang berproses secata terus menerus dan merupakan unsur yang sangat mendasar dalam kehidupan manusia dan juga merupakan setiap jenis yang berjenjang dalam suatu pendidikan formal. Sebagian orang ada yang beranggapan bahwa belajar adalah semata-mata hanya untuk mengumpulkan atau menghapalkan fakta-fakta yang tersedia dalam bentuk informasi atau materi peserta didik.

Penggunaan sebuah metode dalam pembelajaran pendidikan agama Islam oleh guru PAI merupakan suatu syarat yang harus digunakan guna mengetahui teori-teori yang berkaitan dengan belajar. Sebab dengan mengetahui teori-teori belajar tersebut dapat mempermudah dan menghantarkan kesuksesan guru PAI dalam proses pembelajaran untuk mengajarkan materi pembelajarannya dengan menggunakan metode yang sejalan dengan materi yang akan diajarkan kepada siswanya di dalam kelas. ${ }^{2}$

Berhasil atau tidaknya suatu proses belajar mengajar itu dapat kita ketahui dari hasil prestasi yang didapat oleh siswa yang belajar tersebut setelah melalui proses pengajaran. Menurut Fathurrohman dan Sulistyorini prestasi belajar adalah apa yang dicapai oleh siswa setelah melakukan kegiatan belajar. Dalam hal ini, untuk mengetahui prestasi belajar siswa salah satunya dapat diketahui dari kedudukan siswa tersebut di dalam kelas, apakah siswa itu termasuk kelompok yang pandai, sedang atau malah kurang. Prestasi belajar siswa juga dapat dilihat dari tingkat keberhasilannya dalam mempelajari dan mencapai materi pelajaran yang salah satunya dapat dinyatakan dalam bentuk nilai raport dari setiap bidang studi setelah mengalami proses belajar mengajar atau bisa juga dengan melihat apakah siswa terebut aktif atau tidak dalam mengikuti proses pembelajaran di dalam kelas. ${ }^{3}$

Berdasarkan pengalaman peneliti ketika melakukan praktek profesi keguruan (PPK) dapat dilihat bahwa sedikit siswa yang senang belajar. Hal ini dikarenakan kebanyakan siswa itu mengalami kesulitan belajar, siswa tidak tertarik dalam mengikuti pelajaran yang berlangsung didalam kelas karena merasa bosan dan ngantuk sehingga penyerapan informasi menjadi tidak maksimal. Hal tersebut mungkin ada kaitannya dengan gaya belajar yang diterapkan oleh siswa dan juga guru PAI yang mengajar dengan menggunakan metode yang tidak pernah berganti (monoton). Padahal sebenarnya jika difahami dan disadari tidak ada pelajaran yang membosankan, namun dari penyampaian materi guru PAI yang tidak sesuai dengan gaya belajar siswa atau bahkan metode yang digunakan tidak sesuai dengan materi yang diajarkan sehingga mengakibatkan siswa

untuk Meningkatkan Prestasi Belajar Akuntansi, Surabaya: Kresna Bina Insan Prima, hal 12

2 Syahraini Tambak, (2014), 6 Metode Ilmiah dan Inovatif Pendidikan Agama Islam, Yogyakarta: Graha Ilmu, hal. 245-246

${ }^{3}$ Fathurrahman, (2018), Belajar \& Pembelajaran, Yogyakarta: Kalimedia, hal. 119 
tersebut menjadi bosan dan ngantuk dalam proses pembelajaran. Sehubungan dengan hal ini maka menjadi sebuah keharusan seorang guru untuk dapat mengetahui gaya belajar siswanya.

Dari sedikit uraian yang telah peneliti paparkan diatas, dapat diketahui bahwa prestasi belajar itu dipengaruhi oleh beberapa faktor dan tidak boleh dianggap sepele salah satu dari faktor tersebut, karena faktor satu dengan faktor yang lainnya saling berhubungan. Dilihat dari problematika tersebut, maka dalam hal ini menjadi alasan dilakukan penelitian berjudul "Hubungan antara Gaya Belajar Siswa dengan Prestasi Belajar pada Mapel PAI di SMA Dwiwarna Boarding School Parung Bogor”

\section{METODOLOGI PENELITIAN}

Penelitian ini juga merupakan penelitian korelasi karena tujuan dari penelitian ini untuk mengetahui apakah ada hubungan antara strategi guru dengan kemampuan membaca Al-qur'an kelas XI di SMA Dwiwarna Boarding School Parung Bogor Tahun Ajaran 2019/2020. Penelitian kolerasi termasuk dalam penelitian yang bersifat non eksperimen. Dalam penelitian ini peneliti tidak melakukan suatu perlakuan pada objek penelitian yang sifatnya mengubah kondisi dan objek peneliti tersebut.

Dalam penelitian ini populasinya adalah seluruh siswa kelas XI yang berjumlah 95 siswa pada semester ganjil di SMA Dwiwarna Boarding School Parung Bogor Tahun Ajaran 2019/2020. Teknik pengumpulan data yang dilakukan adalah dengan melakukan observasi dan kuesioner. Observasi dilaksanakan sebelum penelitian, kuesioner dilaksanakan sesudah penelitian kepada siswa kelas XI yang bertujuan untuk mengetahui hubungan gaya belajar siswa terhadap prestasi belajar. Data yang berupa kuesioner/angket dilakukan uji validitas dan reliabilitas terlebih dahulu untuk mengetahui apakah data yang disebar valid dan reliabel sehingga bisa disebarkan untuk penelitian. Uji validitas dan reabilitas menggunakan rumus spss 23.0 for windows sedangkan untuk proses analisis data terdiri dari uji normalitas, dan korelasi yang disajikan dalam bentuk tabel dan interpretasi data yang disajikan dalam bentuk tulisan.

\section{KAJIAN TEORI}

\section{A. Strategi Guru}

a. Pengertian Strategi Guru

Dalam konteks pengajaran, menurut Sabri dalam buku Belajar dan pembelajaran oleh Muhammad Fathurrahman dan Sulistyorini : Strategi dimaksudkan sebagai daya upaya guru dalam menciptakan suatu sistem lingkungan yang memungkinkan terjadinya proses mengajar, agar tujuan pembelajaran yang dirumuskan dapat tercapai dan berhasil guna. $^{4}$

\footnotetext{
${ }^{4}$ Muhammad Fathurrahman, Sulistyorini, (2018), Belajar dan Pembelajaran, Yogyakarta, Kalimedia, hal 100
} 
Strategi belajar mengajar itu tentang bagaimana seorang guru mampu untuk mengembangkan potensi guru dan juga peserta didik beserta sumber daya baik itu berupa sarana dan prasarana agar program itu bisa dimanfaatkan secara baik, dan juga agar bisa mencapai tujuan pembelajaran tersebut. Strategi dibuat untuk bisa menciptakan suatu variasi dalam kegiatan belajar mengajar yang dimana dalam strategi tersebut terdapat suatu tujuan dalam pembelajaran, dalam strategi pembelajaran guru harus bisa untuk memanfaatkan segala sesuatu yang ada disekelilingnya seperti dari fasilitas, sumber daya maupun dari hal yang lainnya.

Strategi pembelajaran harus mengandung penjelasan tentang metode / prosedur dan teknik yang digunakan selama proses pembelajaran berlangsung. Strategi pembelajaran adalah cara-cara yang akan digunakan oleh pengajar untuk memilih kegiatan belajar yang akan digunakan selama proses pembelajaran. Pemilihan tersebut dilakukan dengan mempertimbangkan situasi dan kondisi, sumber belajar, kebutuhan dan karakteristik peserta didik yang dihadapi dalam rangka mencapai tujuan pembelajaran tertentu. ${ }^{5}$

Strategi disusun untuk mencapai tujuan tertentu. Artinya, arah dari semua keputusan penyusunan strategi adalah pencapaian tujuan. Dengan demikian, penyusunan langkah-langkah pembelajaran, pemanfaatan berbagai fasilitas dan sumber belajar semuanya diarahkan dalam upaya pencapaian tujuan. ${ }^{6}$

Strategi pembelajaran lebih menekankan terhadap media pembelajaran yang dimana itu untuk bisa lebih mempermudah siswa akan memahami mata pelajaran tersebut, terlebih dalam zaman digital seperti sekarang ini guru harus bisa lebih mengkaitkan pembelajaran tersebut, seperti dalam pengorganisasian dalam membuat suatu urutan, fakta, konsep, prosedur, dan prinsip yang berkaitan. Dalam segi penyampaian guru pun harus bisa lebih meningkatkan minat siswa terhadap pembelajaran tersebut terlebih dalam pelajaran Pendidikan Agama Islam terlebih dalam meningkatkan minat membaca Al-Qur'an.

Strategi belajar mengajar menurut konsep islami adalah proses belajar mengajar yang dilandasi dengan kewajiban yang dikaitkan dengan niat karena Allah SWT, konsep belajar mengajar garus dilandasi dengan niat ibadah, dan konsep yang memerlukan kreativitas, baik metedeologi, didaktik dan desain pembelajaran sehingga tidak terpaku pada satu teori saja.

b. Jenis-jenis Strategi Pembelajaran

Jenis-jenis strategi dalam Interaksi Guru dengan $\mathrm{Siswa}^{7}$

a) Strategi Tatap Muka

Strategi ini akan lebih baik dengan menggunakan alat peraga. Dalam strategi ini seorang guru memberikan informasi sebuah ilmu pengetahuan

\footnotetext{
${ }^{5}$ Uno, Hamzah B, (2008), Model Pembelajaran Menciptakan Proses Belajar Mengajar yang Efektif dan Efisien, Jakarta, Bumi Aksara, Hal 3

${ }^{6}$ Ngalimun, (2017), Strategi Pembelajaran, Yogyakarta, Parama Ilmu, Hal 8

${ }^{7}$ Isriani Hardini, Dewi Puspitasari, (2012), Strategi Pembelajaran Terpadu, Yogyakarta, Familia, hal
} 
langsung kepada siswa tanpa adanya suatu halangan yang melatar belakangi, sehingga siswa lebih mudah untuk memahami akan pelajaran tersebut, tanpa adanya perantara apapun, namun dalam strategi ini pun memiliki suatu kelebihan dan juga kekurangan.

b) Strategi Pengajaran Melalui Medial

Guru tidak langsung kontak dengan siswa, tetapi guru "mewakilkan" kepada media. Siswa berinteraksi dengan media. Dalam strategi ini pun seorang guru menggunakan suatu media, seperti misalnya media elektronik: laptop, komputer. Adapun media lain yang bisa digunakan seperti menggunakan suatu benda yang dapat mempermudah dalam kegiatan belajar mengajar.

c. Macam-macam Strategi Pembelajaran

Strategi belajar yang sudah dijelaskan sebelumnya adalah keseluruhan metode dan prosedur yang digunakan oleh guru dalam meningkatkan hasil belajar siswa. Strategi pembelajaran perlu bervariasi dan sesuai dengan kompetensi dan hasil belajar yang akan dicapai. Menurut Maswan ${ }^{8}$ Klasifikasi strategi belajar mengajar, berdasarkan bentuk dan pendekatan :

a) Ekspository

"Eksposition" (ekspositorik) yang berarti guru hanya memberikan informasi yang berupa teori, generalisasi, hukum atau dalil beserta buktibukti yang mendukung siswa hanya menerima saja informasi yang diberikan oleh guru. Pengajaran telah diolah oleh guru sehingga siap disampaikan kepada siswa, dan siswa diharapkan belajar dari informasi yang diterimanya itu, disebut ekspositorik.

Strategi eksposition menuntut siswa menguasai materi dalam bentuk jadi yang mana bahan disediakan oleh guru tanpa adanya olahan dari siswa. Seperti contoh guru memilih metode ceramah yang mana hanya akan menyampaikan pesan berturut-turut sampai pada pemecahan masalah / eksperimen. Dalam strategi ini bertujuan agar siswa mampu untuk memahami dengan benar dengan cara dapat menjelaskan kembali akan materi yang telah diuraikan oleh guru, dan dalam strategi ini guru berperan sangat dominan.

Menurut Rohani $^{9}$ Pendekatan ekspositori adalah bertolak dari pandangan bahwa tingkah laku kelas pengajaran dan distribusi pengetahuan itu dikontrol dan ditentukan oleh guru. Hakikat mengajar menurut pandangan ini adalah penyampaian ilmu pengetahuan kepada peserta didik yang dipandang sebagai objek yang menerima apa yang diberikan (dari) guru.

b) Pendekatan discovery dan Inquiry

Discovery adalah proses mental dimana siswa mengasimilisasikan suatu konsep atau suatu prinsip. Proses mental misalnya; mengamati, menjelaskan, mengngelompokkan, membuat kesimpulan dan sebagainya. Sedangkan konsep, misalnya; bundar, segi tiga, demokrasi, energi dan sebagai.

\footnotetext{
${ }^{8}$ Maswan, Khoirul Muslimin, (2017), Teknologi Pendidikan, Yogyakarta, Pustaka Pelajar, hal

${ }^{9}$ Rohani, Ahmad, (2010), Pengelolaan Pengajaran (Sebuah Pengantar Menuju Guru Profesional), Jakarta, PT.Rineka Cipta, hal
} 
Model pembelajaran ini dikembangkan oleh seorang tokoh yang bernama Suchman. Suchman meyakini bahwa anak-anak merupakan individu yang penuh dengan rasa ingin tahu akan sesuatu hal. Model ini bertujuan untuk melatih kemampuan siswa dalam meneliti, menjelaskan fenomena, dan memecahkan masalah secara ilmiah. ${ }^{10}$ Inquiry, merupakan perluasan dari discovery (discovery yang digunakan lebih mendalam) artinya, inquiry mengandung proses mental yang lebih tinggi tingkatannya. Misalnya; merumuskan problema, merancang, dan melaksanakan eksperimen, mengumpulkan data, menganalisis data, membuat kesimpulan, dan sebagainya.

c) Pendekatan Konsep

Pendekatan pembelajaran ini dikembangkan berdasarkan karya Jerome Brunner, Jacqueline Goodnow, dan George Austin Brunner. Goodnow dan Austin yakin bahwa lingkungan sekitar manusia beragam, dan sebagai manusia kita harus membedakan, mengkategorikan, dan menanamkan semua itu. Pendekatan pembelajaran perolehan konsep adalah suatu pendekatan pembelajaran yang bertujuan untuk membantu siswa memahami suatu konsep tertentu. Pendekatan pembelajaran ini dapat diterapkan untuk semua umur, dari anak-anak sampai dewasa.

Jalan lain yang dapat ditempuh adalah memasukkan suatu benda ke dalam suatu kelompok tertentu dan mengemukakan beberapa contoh dan kelompok itu yang dinyatakan sebagai jenis kelompok tersebut. Jalan yang kedua inilah yang memungkinkan seseorang mengenal suatu benda atau peristiwa sebagai suatu anggota kelompok tertentu, akibat dan suatu hasil belajar yang dinamakan "konsep".

d. Faktor yang Mempengaruhi Pemilihan Strategi pembelajaran

Banyak faktor yang mempengaruhi pemilihan strategi pembelajaran dan hal yang harus benar-benar diperhatikan oleh orang-orang yang terlibat dalam pembelajaran, baik langsung maupun tidak langsung, diantaranya :

1) Karakteristik Peserta Didik

2) Kompetensi Dasar yang diharapkan

3) Bahan Ajar

4) Waktu yang Tersedia

5) Sarana / Prasarana Belajar

6) Kemampuan / Kecakapan Pengajar Memilih dan Menggunakan Strategi Belajar Mengajar

e. Macam-macam Metode Pembelajaran

Pengertian metode menurut beberapa ahli, sebagai berikut: ${ }^{11}$

1) Menurut Sanjaya, metode adalah cara yang digunakan untuk mengimplementasikan rencana yang disusun dalam kegiatan nyata agar tujuan yang telah disusun tercapai secara optimal.

\footnotetext{
${ }^{10}$ Uno, Hamzah B, (2008), Model Pembelajaran Menciptakan Proses Belajar Mengajar yang Efektif dan Efisien, Jakarta, Bumi Aksara, Hal 16

${ }^{11}$ Suprihatiningrum, Jamil, (2013), Strategi Pembelajaran Teori dan Aplikasi, Jogjakarta, Ar-Ruzz Media, hal 153-154
} 
2) Metode adalah cara yang teratur dan terpikir baik-baik untuk mencapai suatu maksud (di ilmu pengetahuan) cara kerja yang bersistem untuk memudahkan pelaksanaan suatu kegiatan guna mencapai tujuan yang ditentukan. ${ }^{12}$

Melalui penggunaan metode pembelajaran yang tepat, guru dapat merancang strategi kognitif, strategi merancang tujuan pembelajaran PAI dengan maksimal. Kedudukan metode sebagai strategi pembelajaran menggambarkan bahwa dengan mempersiapkan metode pembelajaran yang baik maka secara otomatis juga dapat mempersiapkan strategi guru PAI dalam pembelajaran. ${ }^{13}$

1) Metode Ceramah

Metode ceramah dapat diartikan sebagai cara menyajikan pelajaran melalui penuturan baik itu secara lisan atau penjelasan langsung kepada sekelompok siswa dan juga metode ceramah dikatakan sangatlah ekonomis untuk bisa menyampaikan akan informasi kepada peserta didik, dan juga paling efektif.

2) Metode Demonstrasi

Menurut Sanjaya ${ }^{14}$ Metode demonstrasi adalah metode penyajian pelajaran dengan memperagakan dan mempertunjukkan kepada siswa tentang suatu proses, situasi atau benda tertentu, baik sebenarnya atau hanya sekedar tiruan. Demonstrasi adalah peragaan atau pertunjukkan tentang cara melakukan atau mengerjakan sesuatu.

3) Metode Diskusi

Metode diskusi adalah metode pembelajaran yang menghadapkan siswa pada suatu permasalahan. Tujuan metode ini adalah untuk memecahkan suatu permasalahan, menjawab pertanyaan, menambah dan memahami pengetahuan siswa, serta untuk membuat suatu keputusan. Diskusi bukanalah debat yang bersifat mengasu argumentasi. Diskusi lebih bersifat bertukar pengalaman untuk menentukan keputusan tertentu secara bersamasama.

Diskusi merupakan bentuk tukar pikiran anatara dua orang atau lebih tentang suatu masalah untuk mencapai tujuan tertentu. Metode diskusi merupakan interaksi antara siswa dan siswa atau siswa dengan guru untuk menganalisis, memecahkan masalah, menggali, atau memperdebatkan topik atau permasalahan tertentu. Dalam diskusi selalu ada pokok yang menjadi bahan pembicaraan.

4) Metode Simulasi

Metode ini memindahkan suatu situasi yang nyata ke dalam kegiatan atau ruang belajar karena adanya kesulitan untuk melakukan praktik di dalam situasi yang sesungguhnya. Metode

\footnotetext{
${ }^{12}$ Depdikbud, (2008), Kamus Bahasa Indonesia, Jakarta, Pusat Bahasa Departemen Pendidikan Nasional, hal 952

${ }^{13}$ Syahraini Tambak, (2014), Pendidikan Agama Islam Konsep Metode Pembelajaran PAI, Yogyakarta, Graha Ilmu, hal 79

14 Wina Sanjaya, (2013), Strategi Pembelajaran Berorientasi Standar Proses Pendidikan, Jakarta, Kencana Prenandamedia Group, hal 152
} 
simulasi merupakan bentu metode praktik yang sifatnya untuk mengembangkan ketrampilan peserta belajar (keterampilan mental maupun fisik / teknis). Dalam simulasi, peserta lebih banyak berperan sebagai dirinya sendiri saat melakukan suatu kegiatan / tugas yang benar-benar akan dilakukannya.

5) Metode Eksperimen

Menurut Ahmad Munjin Nasih ${ }^{15}$ metode eksperimen merupakan metode pembelajran dimana guru dan anak didik Bersama-sama mengerjakan sesuatu sebagai latihan praktis dari apa yang telah dipelajari. Dalam proses belajar mengajar dengan metode eksperimen, siswa diberi kesempatan untuk mengalami sendiri atau melakukan sendiri, mengikuti suatu proses, menagamati suatu obyek, keadaan atau proses sesuatu.

\section{B. Membaca al-Qur'an}

a. Pengertian Al-Qur'an

Beberapa pakar bahasa menduga bahwa kata Al-Qur'an berasal dari kata Qara'a, Yaqra'u, Qur'anan. Al-Qur'an merupakan kata khusus yang dipilih sendiri oleh Allah untuk menamai wahyu-Nya yang diturunkan kepada Nabi Muhammad Saw. karenanya, bukan sesuatu yang mengherankan kalau istilah "Al-Qur'an" menjadi istilah yang unik dalam literatur kosa kata bahasa arab. Begitu juga istilah-istilah lain yang sering digunakan di dalam bagian-bagian Al-Qur'an, seperti : ayat, surat, dan sebagiannya.

Allah telah menjadikan Al-Qur'an sebagai mukjizat dalam penjelasan ${ }^{16}$ sehingga, ia menjadi mukjizat yang kekal bagi. Allah SWT berfirman:

Artinya: "dan jika kamu (tetap) dalam keraguan tentang Al Quran yang Kami wahyukan kepada hamba Kami (Muhammad), buatlah[31] satu surat (saja) yang semisal Al Quran itu dan ajaklah penolong-penolongmu selain Allah, jika kamu orang-orang yang benar. Maka jika kamu tidak dapat membuat(nya) - dan pasti kamu tidak akan dapat membuat(nya), peliharalah dirimu dari neraka yang bahan bakarnya manusia dan batu, yang disediakan bagi orang-orang kafir.(QS.AlBaqarah:23-24)

Al-Qur'an adalah sebuah rahasia yang diturunkan oleh zat yang mahatau langit dan bumi. Oleh karena itu, tidak ada yang lebih nikmat bagi akal dan hati selain terkuaknya rahasia tersebut. Hal ini tidak akan tampak terkecuali dengan merenung, menghayati, berfikir, memerhatikan, dan menganalisa. Al-Qur'an terdiri dari lafal-lafal yang dahsyatnya melampaui amukan gelombang tsunami dan kelembutannya melebihi jiwa yang senantiasa bertaut dengan akhirat. Al-Qur'an ibarat ruh dalam jasad. Ia menjelaskan inti dalam sebuah partikel atau energi listrik di alam semesta. Para intelektual saja tidak kuasa untuk menjelaskan kadar dan hakikatnya.

b. Faktor yang Mempengaruhi Kemampuan Membaca Al-Qur'an

${ }^{15}$ Ahmad Munjin Nasih, Lilik Nur Kholidah, (2013), Metode dan Teknik Pembelajaran Pendidikan Agama Islam, Bandung, PT.Refika Aditama, hal

${ }^{16}$ Raghib As-Sirjani,Abdurrahman Abdul Khaliq,(2013), Cara Cepat Hafal Al-Qur'an, Solo, Aqwam, hal 15 
Kemampuan membaca merupakan hasil interaksi berbagai faktor yang mempengaruhinya baik dari dalam diri maupun luar diri individu. Pengenalan terhadap faktor-faktor yang mempengaruhi kemampuan membaca penting sekali artinya dalam rangka membantu murid dalam mencapai prestasi yang sebaik-baiknya.

Yang tergolong faktor internal adalah :

1. Inteligensi (Kecakapan)

2. Perhatian

3. Bakat

4. Motivasi

Selain dari faktor internal terdapat juga faktor eksternal, sebagai berikut:

1. Faktor keluarga

2. Faktor sekolah

3. Faktor lingkungan

c. Keutamaan Membaca Al-Qur'an

Membaca Al-Qur'an itu nikmat. Namun, tidak semua orang dapat merasakan kenikmatan itu. Sebab, ternyata membaca saja tidak cukup, dibutuhkan penghayatan dan pemahaman untuk bisa merasakan kenikmatan itu.

Allah Swt berfirman ${ }^{17}$ :

Artinya: "Dan apabila kamu membaca Al Quran niscaya Kami adakan antara kamu dan orang-orang yang tidak beriman kepada kehidupan akhirat, suatu dinding yang tertutup. Dan Kami adakan tutupan di atas hati mereka dan sumbatan di telinga mereka, agar mereka tidak dapat memahaminya. dan apabila kamu menyebut Tuhanmu saja dalam Al Quran, niscaya mereka berpaling ke belakang karena bencinya(46) (QS.Al-Isra: 45-46)

Menurut Adhim ${ }^{18}$ keutamaan membaca Al-Qur'an diantaranya sebagai berikut :

1) Perniagaan yang tidak akan rugi

2) Menjadi yang terbaik

3) Bersama malaikat pembawa kitab yang mulia dan baik.

4) Seumpama buah utrujah yang wangi dan lezat

5) Derajat yang tinggi disisi Allah

6) Mendapat syafaat di hari kiamat

7) Boleh dengki pada orang yang membaca Al-Qur'an

8) Mendapat kebaikan berlipat ganda

9) Tidak membaca Al-Qur'an = Rumah yang runtuh

10) Memperoleh tingkatan surga yang tinggi

Keutamaan Bacaan Al-Qur'an dan Pembacanya Ibnu Mas'ud Ra meriwayatkan bahwa Nabi Saw bersabda:

\footnotetext{
${ }^{17}$ Hammud bin Abdullah al Mathar, (2019), Keutamaan dan Pahala Besar Membaca Al-Qur'an, Jakarta, Daarul Haq, Hal 5

${ }^{18}$ Said Abdul Adhim, (2013), Nikmatnya Membaca Al-Qur'an, Solo, Aqwam Media Profetika hal 14-19
} 


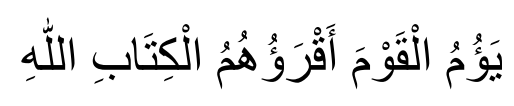

Artinya: "Orang yang berhak menjadi imam bagi suatu kaum adalah yang paling pandai membaca Kitabullah. (HR. Muslm 1564)

Banyak dalil yang menyatakan bahwa membaca Al-Qur'an itu lebih utama dari pada tasbih, dan zikir-zikir laainnya.

d. Tata cara dan Adab Membaca Al-qur'an

Menurut Azis menjelaskan Imam Jalaluddin al-Suyuthi, sebagaimana ditulis kembali oleh Muhammad bin Alawi al-Maliki al-Hasni dalam sebuah ringkasan yang berjudul "Zubdah al-itqan fi Ulum al-Qur'an". Menerangkan tentang beberapa adab dalam membaca Al-Qur'an. Diantara adab-adab tersebut adalah :

1) Hendaknya suci dari hadas kecil.

2) Disunahkan berada di tempat yang suci

3) Disunnahkan membaca sambal duduk, menghadap kiblat, keadaan tenang, menundukkan kepala dan khusyu'.

4) Disunnahkan bersiwakan sebelumnya, untuk menjaga kesucian mulut dan memuliakan Al-Qur'an.

5) Disunnahkan membaca ta'awudz.

6) Hendaknya membaca basmallah pada setiap membaca awal surat, kecuali surat bara'ah.

7) Disunnahkan membaca dengan tartil (pelan-pelan sambal memperhatikan tajwidnya)

8) Disunnahkan merenungi dan memahami kandungannya. Sebab hal itu merupakan maksud dan tuntutan yang mulia.

9) Disunnahkan menangis (atau berusaha untuk menangis)

e. Hikmah Membaca Al-Qur'an

Al-Qur'an merupakan kitab suci yang diturunkan Allah SWT kepada Nabi Muhammad SAW, sebagai salah satu rahmat yang tiada taranya bagi alam semesta. Oleh sebab itu setiap orang yang mempelajari Al-Qur'an akan Ybertambah cintanya kepadanya, cinta untuk membaca, mempelajari, memahami serta mengamalkan dan mengajarkannya, sampai merata rahmat-Nya dirasakan dan dihayati oleh penghuni alam semesta.

1) Al-Qur'an itu sebagai obat hati

Al-Qur'an merupakan mukjizat yang luar biasa yang diberikan kepada Nabi Muhammad SAW sebagai kalam illahi menyimpan banyak rahasia yang tak mampu dijangkau oleh akla manusia yang sanagat terbatas. Menurut Romdoni ${ }^{19}$ Jika dengan membaca Al-fatihah dapat menyembuhkan orang sakit, dengan izin Allah, tentu orang yang hafal seluruh Al-Qur'an akan lebih luar biasa dalam menyembuhkan penyakit.

${ }^{19}$ Romdoni Massul, (2014), metode cepat menghafal dan memahami ayat-ayat Al-Qur'an, Yogyakarta, Lapal Indonesia, hal 115 
Artinya: (yaitu) orang-orang yang beriman dan hati mereka manjadi tenteram dengan mengingat Allah. Ingatlah, hanya dengan mengingati Allah-lah hati menjadi tenteram.(QS.Ar-Ra'd : 28)

2)Setiap Satu Huruf Al-Qur'an mengandung 10 Pahala

Rasulullah SAW menegaskan, barangsiapa yang membaca satu huruf Al-Qur'an, ia akan mendapat ganjaran 1 pahala dan satu pahala dilipat gandakan hingga 10 kali. Sementara itu, Al-Qur'an terdiri atas 322.604 huruf. Jika huruf tersebut dikalikan sepuluh pahala atau kebaikan, kita kan mendapatkan 32.260.040 kebaikan. Setiap kebaikan lebih baik dari pada dunia.

Keutamaan Al-Qur'an sungguh sangat luar biasa. Bahkan satu hruf di dalam AlQur'an saja mengandung 10 pahala. Katakanlah jika kita membaca surat Al-fatihah, maka sudah berapa banyak jumlah pahala yang kita peroleh.

3) Hafal Al-Qur'an Lahirkan Kebahagian

Sesungguhnya orang yang dekat dengan ayat-ayat Al-Qur'an hatinya senantiasa diselimuti dengan ketentraman dan ketenangan. Menghafal Al-Qur'an dapat membuat seseorang semakin sabar dan teguh dalam menghadapi segala macam kesulitan hidup, juga akan memperoleh kebahagiaan yang tak terhingga. Ketika kita menghafal AlQur'an, kita dapat mengubah cara pandang kita dalam segala hal yang berada di sekeliling kita.

\section{4) Terapi Ibu Hamil dengan Bacaan Al-Qur'an}

Para ilmuwan menjelaskan, janin dalam kandungan seorang ibu setelah 42 malam mulai berinteraksi dengan pengaruh-pengaruh eksternal dan ia mulai terpengaruh oleh suara-suara yang ia dengar sedaqng ia berada dalam perut ibunya. Oleh karena itu, seorang ibu harus mendengarkan Al-Qur'an kepada janin yang berada dalam kandungannya. Apalagi setelah melahirkan, sang ibu harus tetap memperdengarkan ayatayat Al-Qur'an kepada anaknya. Dengan begitu, sel-sel otak dan hati anak itu akan terpengaruh oleh ayat-ayat Al-Qur'an, yang merupakan firman Allah.

5) Al-Qur'an Sebagai Budi Pekerti

Nabi bersabda yang artinya: "Seorang Mukmin adalah cermin bagi Mukmin yang lain ...” (HR.Abu Daud). Al-Qur'an menjadi sangat terpelihara keaslian dan kesuciannya. Sebagai bentuk atas jaminan kemurniannya, Allah SWT berfirman:

Artinya: Sesungguhnya Al Quran ini memberikan petunjuk kepada (jalan) yang lebih Lurus dan memberi khabar gembira kepada orang-orang Mu'min yang mengerjakan amal saleh bahwa bagi mereka ada pahala yang besar,(QS.Al-Isra:9)

Al-Qur'an adalah lautan yang luas, tenang, jernih, dan suci. Kedalaman makna kandungannya hanya dapat di mengerti oleh mereka yang berhati bersih. Tiada perasaan sempit di dada, berani menampakkan kebenaran isi kandungannya. Jiwa Muslim selalu mendapatkan pengajaran, karena kedalaman yang dikandungnya. 


\section{6) Al-Qur'an Merupakan Pedoman Kehidupan}

Al-Qur'an adalah kalamullah, firman Allah SWT yang diturunkan kepada Nabi Muhammad SAW selama 23 tahun. Al-Qur'an merupakan kitab suci umat Islam yang merupakan sumber petunjuk dalam beragama dan pembimbing dalam menjalani kehidupan di dunia dan akhirat.

Membaca Al-Qur'an merupakan langkah pertama dalam berinteraksi dengannya, kemudian diteruskan dengan tadabbur, yaitu dengan merenungkan dan memahami mengajarkannya. Di antara membaca Al-Qur'an adalah sebagaimana firman Allah:

Artinya: "dan bacakanlah apa yang diwahyukan kepadamu, Yaitu kitab Tuhanmu (Al Quran). tidak ada (seorangpun) yang dapat merobah kalimat-kalimat-Nya. dan kamu tidak akan dapat menemukan tempat berlindung selain dari padanya. (QS.AlKahfi: 27)

\section{HASIL PENELITIAN DAN PEMBAHASAN}

Pada bagian ini akan dijelaskan temuan dari hasil penelitian yang telah dilakukan terkait hubungan antara strategi guru terhadap kemampuan baca Al-Qur'an kelas XI di SMA Dwiwarna Boarding School Parung Bogor.

\section{Deskripsi Data}

Data yang digunakan pada penelitian ini adalah penelitian kolerasi yang termasuk kedalam penelitian bersifat non eksperimen Deskrpisi data dengan metode pada kelas XI IPA dan IPS yang dilakukan untuk mengetahui hubungan antara gaya belajar terhadap prestasi belajar PAI siswa dengan menggunakan kuesioner/angket yang telah diberikan kepada siswa melalui google form. Berikut ini disajikan tabel distribusi frekuensi siswa berdasarkan kecenderungan gaya belajarnya beserta persentasenya:

Tabel IV.24

Distribusi frekuensi strategi guru

\begin{tabular}{|c|c|c|c|c|}
\hline No & Strategi Guru & $\begin{array}{c}\text { Jumlah } \\
\text { siswa }\end{array}$ & Persentase & Kategori \\
\hline 1 & Ekspository & 73 & $97,33 \%$ & Banyak \\
\hline 2 & Discovery/inquiry & 2 & $2,66 \%$ & Kurang \\
\hline 3 & $\begin{array}{c}\text { Pendekatan } \\
\text { Konsep }\end{array}$ & 0 & 0 & Tidak ada \\
\hline
\end{tabular}

Berdasarkan gambar di atas dapat diketahui bahwa besarnya persentase strategi guru ekspository adalah 97,33\%, strategi guru discovery/inquiry persentasenya sebesar 2,66\%, sehingga dapat disimpulkan bahwa kecenderungan strategi guru kelas XI di SMA Dwiwarna Boarding School Parung Bogor adalah ekspository.Berikutnya yaitu kemampuan baca Al-Qur'an. Data tentang kemampuan baca Al-Qur'an diperoleh melalui rekap nilai test baca Qur'an siswa kelas XI Tahun Ajaran 2019/2020 Semester 2. 
Tabel IV.25

Rekapitulasi Hasil Nilai Tes Baca Al-Qur'an Semester Genap (Y)

\begin{tabular}{|c|c|c|c|}
\hline $\begin{array}{c}\text { No } \\
\text { Responden }\end{array}$ & $\begin{array}{c}\text { Nilai } \\
\text { Baca Al- } \\
\text { Qur'an }\end{array}$ & $\begin{array}{c}\text { No } \\
\text { Responden }\end{array}$ & $\begin{array}{l}\text { Nilai Baca } \\
\text { Al-Qur'an }\end{array}$ \\
\hline 1 & 79 & 41 & 78 \\
\hline 2 & 65 & 42 & 81 \\
\hline 3 & 85 & 43 & 88 \\
\hline 4 & 77 & 44 & 77 \\
\hline 5 & 78 & 45 & 79 \\
\hline 6 & 76 & 46 & 75 \\
\hline 7 & 81 & 47 & 86 \\
\hline 8 & 84 & 48 & 78 \\
\hline 9 & 85 & 49 & 75 \\
\hline 10 & 70 & 50 & 79 \\
\hline 11 & 79 & 51 & 98 \\
\hline 12 & 72 & 52 & 96 \\
\hline 13 & 79 & 53 & 89 \\
\hline 14 & 74 & 54 & 77 \\
\hline 15 & 84 & 55 & 97 \\
\hline 16 & 81 & 56 & 91 \\
\hline 17 & 80 & 57 & 78 \\
\hline 18 & 78 & 58 & 91 \\
\hline 19 & 85 & 59 & 74 \\
\hline 20 & 85 & 60 & 85 \\
\hline 21 & 84 & 61 & 79 \\
\hline 22 & 73 & 62 & 86 \\
\hline 23 & 63 & 63 & 82 \\
\hline 24 & 78 & 64 & 87 \\
\hline 25 & 76 & 65 & 85 \\
\hline 26 & 84 & 66 & 77 \\
\hline 27 & 81 & 67 & 85 \\
\hline 28 & 82 & 68 & 88 \\
\hline 29 & 85 & 69 & 87 \\
\hline 30 & 72 & 70 & 81 \\
\hline 31 & 77 & 71 & 84 \\
\hline 32 & 78 & 72 & 80 \\
\hline 33 & 89 & 73 & 84 \\
\hline 34 & 76 & 74 & 78 \\
\hline 35 & 81 & 75 & 95 \\
\hline 36 & 79 & 73 & 84 \\
\hline 37 & 81 & 74 & 78 \\
\hline 38 & 96 & 75 & 95 \\
\hline 39 & 81 & Jumlah & 6098 \\
\hline 40 & 75 & Rata-rata & 81,306667 \\
\hline
\end{tabular}

Tabel diatas menunjukan bahwa kemampuan baca Qur'an di ambil dari nilai tes baca Qur'an Semester Akhir Tahun Ajaran 2019/2020. Dari tabel di atas dapat diketahui 
bahwa nilai rata-rata siswa kelas XI di SMA Dwiwarna Boarding School Parung Bogor dengan frekuensi 75 siswa berjumlah 81,30. Hasil nilai tersebut termasuk kategori "baik". Pengkategorian tersebut berdasarkan tabel berikut ini:

Tabel IV.26

\section{Kriteria Kemampuan Baca Al-Qur'an}

One-Sample Kolmogorov-Smirnov Test
\begin{tabular}{|ll|r|}
\hline N & $\begin{array}{r}\text { Unstandardized } \\
\text { Residual }\end{array}$ \\
\hline Normal Parameters ${ }^{\mathrm{a}, \mathrm{b}} \quad$ Mean & 75 \\
& Std. Deviation & .0000000 \\
Most Extreme Differences & Absolute & .65692400 \\
& Positive & .070 \\
& Negative & .070 \\
Test Statistic & -.067 \\
Asymp. Sig. (2-tailed) & .070 \\
a. Test distribution is Normal. & $.200^{\mathrm{c}, \mathrm{d}}$ \\
\hline b. Calculated from data. & \\
c. Lilliefors Significance Correction. & \\
d. This is a lower bound of the true significance.
\end{tabular}

\begin{tabular}{|c|c|c|}
\hline NO & KETERANGAN & RENTANG NILAI \\
\hline 1 & Sangat Baik & $93-100$ \\
\hline 2 & Baik & $85-92$ \\
\hline 3 & Cukup & $77-84$ \\
\hline 4 & Kurang & $69-76$ \\
\hline 5 & Sangat Kurang & $61-68$ \\
\hline
\end{tabular}

\section{Uji Normalitas}

Pengujian normalitas data digunakan untuk mengetahui apakah data berdistribusi normal atau tidak. Pengujian ini dilakukan melalui program spss 23.0 for windows. Berikut hasil data uji normalitas:

\section{Tabel IV.27}

\section{Uji Normalitas}

Dari Tabel diatas menunjukan nilai tes kolmogorov-smirnov dengan nilai signifikan 0,200 lebih besar dari 0,05, sehingga dapat disimpulkan data yang digunakan berdistribusi normal.

\section{Uji Korelasi}

Kemudian dari hasil penelitian di atas, dicari tingkat korelasi Variabel X (Strategi guru) terhadap Variabel Y (Kemampuan membaca Al-Qur'an) dengan menggunakan rumus SPSS sebagai berikut: 
Tabel IV.28

Uji Korelasi

Correlations

\begin{tabular}{|ll|r|r|}
\hline & $x$ & \multicolumn{1}{|c|}{$y$} \\
\hline$X$ & Pearson Correlation & 1 & .090 \\
& Sig. (2-tailed) & & .444 \\
& N & 75 & 75 \\
\hline Y & Pearson Correlation & .090 & 1 \\
& Sig. (2-tailed) & .444 & \\
N & 75 & 75 \\
\hline
\end{tabular}

Tabel IVIV.29

Interprestasi Nilai

\begin{tabular}{|c|c|}
\hline Besarnya Nilai & Interprestasi \\
\hline $0,00-0,20$ & Tidak \\
\hline $0,20-0,40$ & Kurang \\
\hline $0,40-0,70$ & Sedang \\
\hline $0,70-0,90$ & Kuat \\
\hline $0,90-1000$ & Sangat kuat \\
\hline
\end{tabular}

Kriteria pengujian adalah sebagai berikut:

Ha ditolak, jika nilai sig. (2-tailed) $<0,05$

Ha diterima, jika nilai sig. (2-tailed) $>0,05$

Ho ditolak, jika nilai sig. (2-tailed $)<0,0$

Ho diterima, jika nilai sig. (2-tailed $)>0,05$

Setelah dilakukan uji korelasi dengan rumus korelasi pearson dengan taraf signifikan 5\%, diketahui bahwa nilai korelasi variabel $\mathrm{X}$ dan $\mathrm{Y}$ sebesar 0,90 apabila dilihat dari tabel interpretasi nilai yang diperoleh yaitu 0,90 yang terletak antara interval 0,70-0,90 bahwa terdapat hubungan antara strategi guru dengan kemampuan baca Al-Qur'an, dan korelasi disini bersifat kuat.

\section{SIMPULAN}

Hasil penelitian yang peneliti lakukan menunjukkan bahwa dari 75 siswa kelas XI SMA Dwiwarna Boarding School Parung Bogor yang mengisi Skala Strategi guru ada 73 siswa $(97,33 \%)$ memiliki kecenderungan Strategi guru Ekspository, ada 2 siswa 
$(2,66 \%)$ yang kecenderungan strategi guru discovery/inquiry. Hal ini menunjukkan bahwa strategi guru yang dominan dimiliki oleh siswa kelas XI SMA Dwiwarna Boarding School Parung Bogor tahun ajaran 2019/2020 adalah strategi guru Ekspository

Selain itu mengenai data tentang kemampuan baca Al-Qur'an siswa yang diperoleh melalui rekap nilai tes baca Qur'an kelas XI Tahun Ajaran 2019/2020 Semester 2 menunjukan bahwa nilai rata-rata siswa kelas XI di SMA Dwiwarna Boarding School Parung Bogor dengan frekuensi 75 siswa berjumlah 81.30 yang mana hasil nilai tersebut termasuk kategori "baik".

Berdasarkan data dari hasil penelitian yang telah diuraikan sebelumnya membuktikan bahwa terdapat hubungan strategi guru dengan kemampuan baca AlQur'an. Hal tersebut terlihat dari hasil angket masing-masing variabel. Setelah dilakukan uji korelasi dengan taraf signifikan 5\% maka nilai korelasi sebesar 0,90 yang terletak antara interval 0,70-0,90 yang artinya terdapat hubungan kuat.

Kemudian dengan melihat tabel pada " $r$ " dengan nilai signifikasinya di peroleh "r" tabel sebesar 0,2272. Dengan demikian pada taraf signifikasi 5\% "r" hitung =0,90> dari " $r$ " tabel $=0,2272$, berarti hipotesis alternatif $(\mathrm{Ha})$ diterima.

Berdasarkan hasil penelitian yang telah dilakukan tersebut, ternyata banyak pengaruh strategi guru terhadap kemampuan baca Qur'an siswa.

\section{DAFTAR PUSTAKA}

Rumpakawati W, (2015), Pembelajaran Kooperatif dengan Metode Numbered Heads Togther untuk Meningkatkan Prestasi Belajar Akuntansi, Surabaya: Kresna Bina Insan Prima

Syahraini Tambak, (2014), 6 Metode Ilmiah dan Inovatif Pendidikan Agama Islam, Yogyakarta: Graha Ilmu

Fathurrahman, (2018), Belajar \& Pembelajaran, Yogyakarta: Kalimedia

Muhammad Fathurrahman, Sulistyorini, (2018), Belajar dan Pembelajaran, Yogyakarta, Kalimedia

Uno, Hamzah B, (2008), Model Pembelajaran Menciptakan Proses Belajar Mengajar yang Efektif dan Efisien, Jakarta, Bumi Aksara

Ngalimun, (2017), Strategi Pembelajaran, Yogyakarta, Parama Ilmu

Isriani Hardini, Dewi Puspitasari, (2012), Strategi Pembelajaran Terpadu, Yogyakarta, Familia

Maswan, Khoirul Muslimin, (2017), Teknologi Pendidikan, Yogyakarta, Pustaka Pelajar 
Rohani, Ahmad, (2010), Pengelolaan Pengajaran (Sebuah Pengantar Menuju Guru Profesional), Jakarta, PT.Rineka Cipta

Suprihatiningrum, Jamil, (2013), Strategi Pembelajaran Teori dan Aplikasi, Jogjakarta, Ar-Ruzz Media

Depdikbud, (2008), Kamus Bahasa Indonesia, Jakarta, Pusat Bahasa Departemen Pendidikan Nasional

Syahraini Tambak, (2014), Pendidikan Agama Islam Konsep Metode Pembelajaran PAI, Yogyakarta, Graha Ilmu

Wina Sanjaya, (2013), Strategi Pembelajaran Berorientasi Standar Proses Pendidikan, Jakarta, Kencana Prenandamedia Group

Ahmad Munjin Nasih, Lilik Nur Kholidah, (2013), Metode dan Teknik Pembelajaran Pendidikan Agama Islam, Bandung, PT.Refika Aditama

Raghib As-Sirjani,Abdurrahman Abdul Khaliq,(2013), Cara Cepat Hafal Al-Qur'an, Solo, Aqwam

Hammud bin Abdullah al Mathar, (2019), Keutamaan dan Pahala Besar Membaca AlQur'an, Jakarta, Daarul Haq

Said Abdul Adhim, (2013), Nikmatnya Membaca Al-Qur'an, Solo, Aqwam Media Profetika

Romdoni Massul, (2014), Metode cepat menghafal dan memahami ayat-ayat Al-Qur'an, Yogyakarta, Lapal Indonesia 